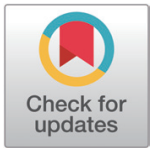

Received: Sep 3, 2020

Revised: Oct 5, 2020

Accepted: Nov 14, 2020

*Corresponding author

Jungseok Choi

Department of Animal Science,

Chungbuk National University,

Cheongju 28644, Korea.

Tel: +82-43-261-2551

E-mail: jchoi@chungbuk.ac.kr

Copyright $\odot 2021$ Korean Society of Animal Sciences and Technology.

This is an Open Access article distributed under the terms of the

Creative Commons Attribution

Non-Commercial License (http://

creativecommons.org/licenses/by-

$\mathrm{nc} / 4.0 /$ ) which permits unrestricted

non-commercial use, distribution, and

reproduction in any medium, provided

the original work is properly cited.

ORCID

Sangkeun Jin

https://orcid.org/0000-0002-8983-5607

Jungseok Choi

https://orcid.org/0000-0001-8033-0410

Competing interests

No potential conflict of interest relevant

to this article was reported.

Funding sources

This work was supported by

Gyeongnam National University of

Science and Technology Grant in 2020-

2021.

\section{Effects of porcine blood plasma on the emulsion stability, physicochemical characteristics and textural attributes of emulsified pork batter}

\author{
Sangkeun $\mathrm{Jin}^{1}$ and Jungseok Choi ${ }^{2 *}$ \\ ${ }^{1}$ Department of Animal Resources Technology, Gyeongnam National University of Science and \\ Technology, Jinju 52725, Korea \\ ${ }^{2}$ Department of Animal Science, Chungbuk National University, Cheongju 28644, Korea
}

\section{Abstract}

This study was conducted to determine the effects of addition of porcine blood plasma (PBP) to the emulsified pork batter as a substitute for the soy protein isolate (SPI) or sodium caseinate (SC) on the emulsion stability and physicochemical and textural properties of the emulsified pork batter. A total of 10 treatments were no addition and $0.5 \%, 1.0 \%$, and $1.5 \%$ addition with each of SPI, SC, and PBP. The moisture and fat losses of the pork emulsion after cooking decreased with increasing percentage of any of SPI, SC, and PBP $(p<0.05)$. Further, moisture loss was less for the PBP treatment than for SPI and SC $(p<0.05)$. The lightness, redness, and whiteness of the emulsified pork batter decreased $(p<0.05)$ due to any of the SPI, SC, and PBP treatments whereas the yellowness and the chroma and hue values increased. The lightness, redness, yellowness, and chroma and hue values differed also among the SPI, SC, and PBP treatments $(p<0.05)$; however, the numerical difference between any two types of substitutes was less than $8 \%$ of the two corresponding means in all of these variables. Textural properties, including the hardness, cohesiveness, springiness, gumminess, chewiness, and adhesiveness, were not influenced by any of the SPI, SC, and PBP treatments $(p>0.05)$, except for greater gumminess and chewiness for the PBP treatment than for SC. The present results indicate that PBP is comparable or even superior to SPI or SC in its emulsion-stabilizing effect and therefore could be used a substitute for the latter as a non-protein ingredient of pork emulsion batter.

Keywords: Porcine blood plasma, Soy protein isolate, Sodium caseinate, Pork emulsion, Emulsion stability

\section{INTRODUCTION}

The addition of non-meat proteins into processed meat products has been done for increase of binding ability, reduction of raw material loss, and prevent loss of moisture and fat [1,2]. Protein acts as a bridge 
Acknowledgements Not applicable.

Availability of data and material Upon reasonable request, the datasets of this study can be available from the corresponding author.

\section{Authors' contributions}

Conceptualization: Jin S, Choi J.

Data curation: Choi J.

Formal analysis: Jin S, Choi J.

Methodology: Jin K, Choi J.

Software: Jin S, Choi J.

Validation: Jin S.

Investigation: Choi J.

Writing - original draft: Jin S, Choi J.

Writing - review \& editing: Jin S, Choi J.

Ethics approval and consent to participate This article does not require IRB/IACUC approval because there are no human and animal participants. between fat and water to form meat emulsion [3,4]. Various proteins derived from soy, milk, egg, and animal skin are commonly used in the manufacturing of meat products [5-7]. It has also been studied that blood proteins including blood plasma and blood components resulting from animal slaughter can be used as protein sources for food materials $[8,9]$.

According to the statistics of American soybean association, in 2015, 320.2 million metric tons of soybeans were produced worldwide, of which 218.7 million metric tons were available for consumption [10], and it accounts for $71 \%$ of the total plant protein source of humanity. Soy proteins also have outstanding emulsifying capacity and stability in meat products [11-13]. Thus, soy protein has long been widely used in meat products. Soy proteins are divided into soy protein concentrate (more than $70 \%$ protein content) and soy protein isolate (SPI, more than $90 \%$ protein content) [14].

Sodium caseinate (SC) is produced by attaching sodium to casein separated from skimmed milk with acid treatment (citric or carbonic acid) [15]. The casein protein in combination with sodium is more soluble in water than pure casein proteins.

Casein accounts for approximately $80 \%$ of milk protein, and it has excellent emulsifying capacity and emulsion stability. SC is excellent in solubility, surface activity, heat resistance and water retention was used as an emulsifier [16]. However, $\mathrm{SC}$ has the disadvantage is expensive compared to other non-meat proteins [17]. Currently, consumers are gradually reluctant to purchase food containing SC because it is classified as a synthetic additive in the process of attaching sodium.

Meat consumption is constantly increasing globally [18]. Therefore, slaughtering of livestock is also increasing every year. Slaughter blood production has been estimated to be 6.7 liters per pig $(100 \mathrm{~kg})$ and 27 liters per cattle $(450 \mathrm{~kg})$ [19]. In 2015, world total slaughter heads of swine and cattle were 1,246 million and 231 million respectively [20]. If the total amount of slaughter blood is calculated using slaughtered heads of swine and cattle, the total blood volume is approximately 15 billion litters. Assuming the yield of approximately 50\%, total slaughter blood volume is calculated to be 7,294.5 million liters. Currently, some researchers have attempted to recycle unused blood as a functional material and food resource, but it was not practical due to the high cost of blood processing [21,22]. Animal blood is composed of $79.14 \%$ moisture, $19.40 \%$ of organic matter, and $1.46 \%$ of inorganic matter, and protein of organic matter is $18.22 \%$ including albumin $2.08 \%$, globulin 1.99\%, fibrinogen $0.12 \%$ and hemoglobin $14.02 \%$ [19]. These blood proteins can be used as an emulsifier, colorant, fertilizer, medicine, and so on.

In previous studies, the addition of $2 \%$ blood plasma to meat product improved the yield by 4\%-5\% [23], and blood plasma could also be used as an alternative binding agent for egg white protein, and in particular, it showed higher binding ability than egg white protein [5]. In addition, there was also an important study that heat-induced gelation could be changed by $\mathrm{pH}$ because of the different protein components (serum and albumin) in blood plasma [24]. However, no studies have logically compared and analyzed the physicochemical characteristics of pork batters according to the horizontal levels of addition of non-meat proteins, which are mainly used most frequently in the meat processing industry.

Thus, the purpose of this study was to determine effect of porcine blood plasma (PBP) on physico-chemical characteristics of pork emulsion as emulsifier compared to that of commercial additives, SPI or SC, and to determine whether slaughter blood protein could be used in meat products as a binder.

\section{MATERIALS AND METHODS}

\section{Preparation of pork emulsion}

Commercial SPI and SC were bought from Dongbang foodmaster (Eumseong, Korea). Porcine 
blood was freshly taken right after slaughter and immediately moved to laboratory for plasma preparation. Ethylenediaminetetracetic acid was added to obtained blood at $2 \mathrm{~g}$ per liter. Blood was placed immediately in an ice slash and transferred to the laboratory within $30 \mathrm{~min}$. Then, samples were centrifuged (SUPRA 25K, Hanil Science, Gimpo, Korea) at 8,000×g for 15 mins at $4^{\circ} \mathrm{C}$. Separated plasma was completely freeze-dried (PVTFD10R, Ilshinlab, Dongducheon, Korea) at $-50^{\circ} \mathrm{C}$. Fresh pork (Biceps femoris) and backfat from Landrace $\times$ Yorkshire $\times$ Duroc pigs were purchased from a local slaughter house. The pork was ground twice into $5 \mathrm{~mm}$ pieces with excess connective tissue removed.

Both PBP and commercial proteins used in this study were prepared in $10 \mathrm{~kg}$ units of emulsion. The basic recipe of emulsified pork batter consisted of $72.4 \%$ meat, $11.2 \%$ backfat, $14.9 \%$ ice, and $1.5 \%$ refined salt. Minced meat was ground for $1 \mathrm{~min}$ in a bowl cutter (Talsa K30, DSL Food Machinery, Burton-on-Trent, UK), then, $1.5 \%$ white salt and half of ice (1/2) were subsequently added to the batter and mixed for $2 \mathrm{~min}$. As the experimental design (Control, no added; SPI 0.5\%, $1 \%, 2 \%$; SC $0.5 \%, 1 \%, 2 \%$; and, PBP $0.5 \%, 1 \%, 2 \%$ ), respective groups were prepared (Table 1 ). After $1 \mathrm{~min}$, fat was added and mixed for $1 \mathrm{~min}$. The remained ice (1/2) was put into a batter, and further mixed for 3 min at a high speed (bowl speed: $24 \mathrm{rpm}$; knife shaft speed: 2,840 rpm) to take a final emulsion batter. At this time, the temperature of batter was below at $11.5^{\circ} \mathrm{C}$. The batters were stuffed into fibrous casings (Nalo Top, Kalle GmbH, Wiesbaden, Germany; 70-mm diameter) using a stuffer (IS-8, Sirman, Pieve PD, Italy). The stuffed emulsions were heated in a cooking chamber (Smoker 851, Thematec Food Industry, Seongnam, Korea) until the internal temperature going up $75^{\circ} \mathrm{C}$. The cooked emulsion samples were then cooled at $4^{\circ} \mathrm{C}$ and used for subsequent physicochemical analyses.

\section{Physico-chemical analysis}

\section{Emulsion stability (ES)}

The ES was analyzed by the modified method of Bloukas and Honikel [25]. The emulsion batter was filled in to a pre-weighed graduated test tubes (Pyrex, Chojalab, Seoul, Korea, volume: $15 \mathrm{~mL}$, graduated units: $0.2 \mathrm{~mL}$ ). The test tubes were capped and heated for $30 \mathrm{~min}$ in a water bath to a core temperature of $75 \pm 1^{\circ} \mathrm{C}$. After cooling down $4 \pm 1^{\circ} \mathrm{C}$, water and fat separated in each graduated test tube were read out. The ES values were calculated as separation of water, fat and sum of them. The separated water and fat were calculated as a percentage to the total loss of the emulsified pork batter.

Table 1. Formulations of pork emulsions containing a non-meat ingredient (\%)

\begin{tabular}{|c|c|c|c|c|c|c|c|c|c|}
\hline \multirow{2}{*}{ Non-meat ingredients (NMI) } & \multirow{2}{*}{ Treatments } & \multicolumn{7}{|c|}{ Raw materials } & \multirow{2}{*}{ Total } \\
\hline & & Pork & Fat & Water & Salt & & NMI & & \\
\hline Control & 1 & 72.4 & 11.2 & 14.9 & 1.5 & - & - & - & 100 \\
\hline \multirow[t]{3}{*}{ Soy protein isolated (SPI) } & 2 & 71.9 & 11.2 & 14.9 & 1.5 & 0.5 & - & - & 100 \\
\hline & 3 & 71.4 & 11.2 & 14.9 & 1.5 & - & 1.0 & - & 100 \\
\hline & 4 & 70.4 & 11.2 & 14.9 & 1.5 & - & - & 2.0 & 100 \\
\hline \multirow[t]{3}{*}{ Sodium caseinate (SC) } & 5 & 71.9 & 11.2 & 14.9 & 1.5 & 0.5 & - & - & 100 \\
\hline & 6 & 71.4 & 11.2 & 14.9 & 1.5 & - & 1.0 & - & 100 \\
\hline & 7 & 70.4 & 11.2 & 14.9 & 1.5 & - & - & 2.0 & 100 \\
\hline \multirow[t]{3}{*}{ Porcine blood plasma (PBP) } & 8 & 71.9 & 11.2 & 14.9 & 1.5 & 0.5 & - & - & 100 \\
\hline & 9 & 71.4 & 11.2 & 14.9 & 1.5 & - & 1.0 & - & 100 \\
\hline & 10 & 70.4 & 11.2 & 14.9 & 1.5 & - & - & 2.0 & 100 \\
\hline
\end{tabular}




\section{pH, shear force \& CIE color}

A $10 \mathrm{~g}$ of pork emulsion was weighted into small pieces to which $90 \mathrm{~mL}$ of distilled water was added, and slurry was mixed by a homogenizer (T25B, IKA Sdn. Bhd., Selangor, Malaysia) and the $\mathrm{pH}$ was measured using a $\mathrm{pH}$ meter. The $\mathrm{pH}$ meter was used to measure the $\mathrm{pH}$ of emulsified pork batters with calibration daily by standard buffers of $\mathrm{pH} 4.0(9863 \mathrm{pH}$ buffer solution, Mettler Toledo, Greifensee, Swizerland) and $7.0\left(9865 \mathrm{pH}\right.$ buffer solution, Mettler Toledo) at $25^{\circ} \mathrm{C}$. Shear force of the sample was measured by the Instron 3343 (US/MX50, A\&D, San Jose, CA, USA) with a Warner Bratzler shearing device, in a $100 \mathrm{~mm} / \mathrm{min}$ crosshead speed. Five cores $(2 \times 2 \times 1$ $\mathrm{cm}$ ) of each emulsion were measured, in a crosshead speed of $100 \mathrm{~mm} / \mathrm{min}$. The CIE lightness ( $\left.\mathrm{L}^{*}\right)$, redness $\left(\mathrm{a}^{*}\right)$, and yellowness $\left(\mathrm{b}^{*}\right)$ of emulsified pork batters were measured by a Minolta colorimeter (CR-400, Minolta, Osaka, Japan). Whiteness (W) was determined using the following formula: $L^{*}-3 b^{*}$. The instrument was calibrated using a white plate $\left(L^{*}=93.5, a^{*}=0.3132, b^{*}=0.3198\right)$ and D65 illuminant source. The chroma $\left(\mathrm{C}^{*}\right)$ and hue angle were calculated as $\left(\mathrm{a}^{* 2}+\mathrm{b}^{* 2}\right)$ and $\operatorname{Tan}^{-1}\left(\mathrm{~b}^{*} /\right.$ $\mathrm{a}^{*}$ ), respectively [26]. The color measurements were replicated at five times on the surface of the slices randomly.

\section{Analysis of texture properties}

The textural properties analysis of the cooked batters were measured by the EZTest- $500 \mathrm{~N}$ texture analyzer (TA-XTZ-5, Shimadzu, Kyoto, Japan) with a cylindrical plunger (5 mm diameter, depression speed $=60 \mathrm{~mm} / \mathrm{min}$ ) and a $500 \mathrm{~N}$ load cell. Texture profile variables were obtained from the hardness, cohesiveness, springiness, gumminess and chewiness, adhesiveness.

\section{Statistical analysis}

Randomized complete block design (RCBD) was used confirmation of insight. The data was analyzed by the orthogonal contrast test to find difference between the treatments (Control versus means of PBP + SPI + SC; PBP versus SPI; PBP versus SC), and regressions were used to evaluate the addition levels of non-meat ingredient (NMI). Duncan's multiple range test was used to determine the statistical significance among the means at a 95\% significance level. All data analysis was performed using SAS program for Windows 7.0, version 9.1.4 [27].

\section{RESULTS AND DISCUSSION}

\section{Results}

\section{Physico-chemical properties of pork emulsions}

Results of emulsion stability and physico-chemical properties of pork emulsions added with NMI are summarized in Table 2 . The addition of NMI significantly increased the emulsion stability of pork emulsion. The total loss, percentages of moisture and fat losses in the total loss values of pork emulsions were lower in the treatment groups than control $(p<0.01)$. Especially each $2 \%$ addition group of NMI greatly were improved in the emulsion stability, and the $0.5 \%$ and $2 \%$ PBP additions further reduced the total loss, the percentages of moisture and fat losses in the total loss values of pork emulsion than those of SPI and SC $(p<0.05)$. Of the results of linear and quadratic regressions analysis, the emulsion stability values significantly were decreased as the $\mathrm{PBP}$ addition increases $(p<0.05)$. The $\mathrm{pH}$ values of pork emulsions added with NMI were lower than control $(p$ $<0.01$ ), and the $\mathrm{pH}$ value of pork emulsion added with PBP was lower than those of SPI and SC significantly. In the regression of $\mathrm{pH}$ values of pork emulsions, the NMI addition also showed to decrease all the $\mathrm{pH}$ values of treatments. The addition of NMI significantly affected the shear force 


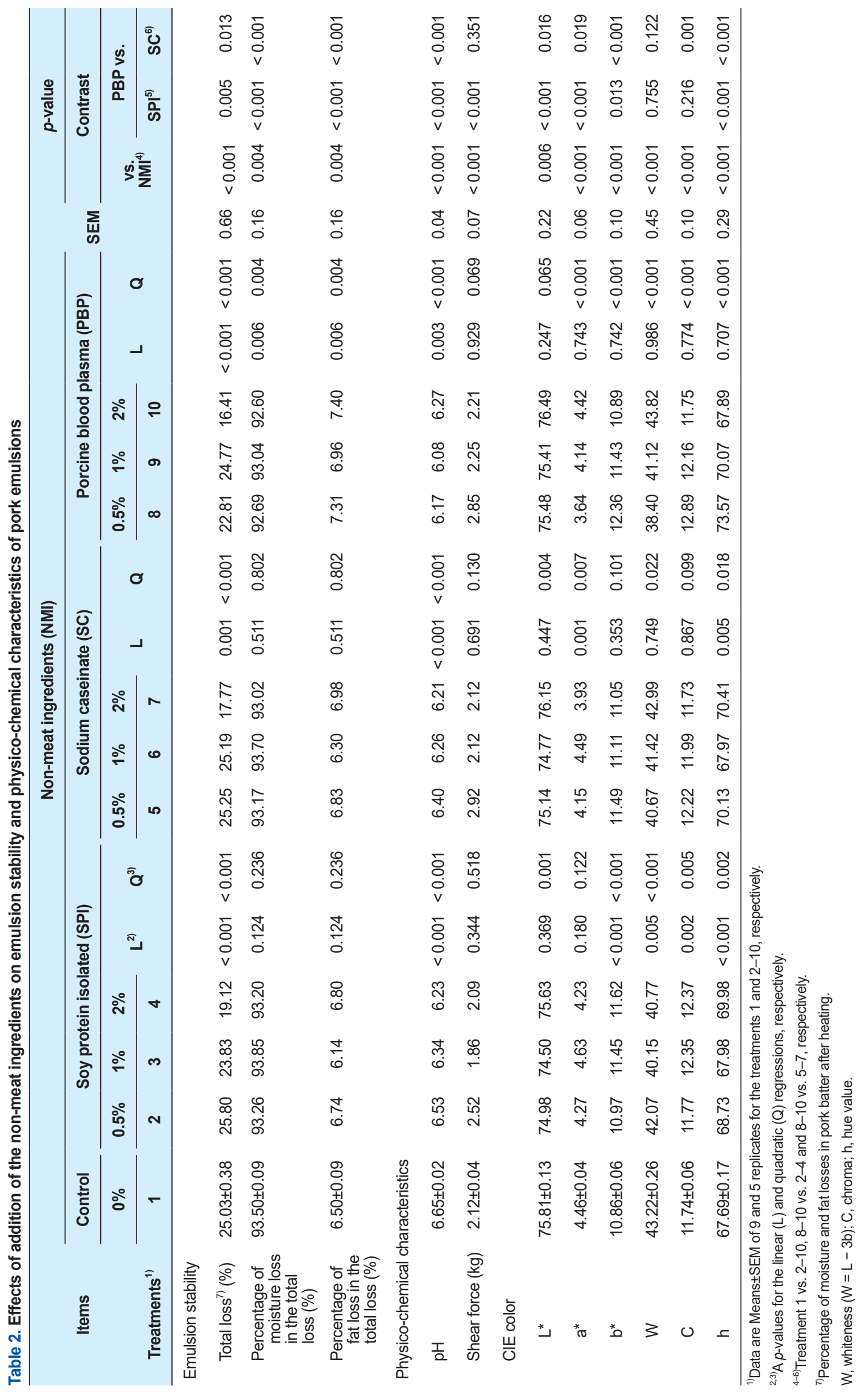


values of pork emulsions compared to the control (1 vs 2-10), and the shear force values of pork emulsions were increased by the addition of $0.5 \% \mathrm{NMI}(p<0.01)$. However, the addition of $1 \%$ and $2 \%$ NMI did not show any remarkable results compared with the shear force values of $0.5 \%$ addition, because the regression results of shear force were not significant by the addition levels (1\%-2\%) of NMI. The shear force value of pork emulsion with PBP was higher than that of pork emulsion with SPI $(p<0.01)$, whereas there was no significantly different shear force between PBP and $\mathrm{SC}$ treatments.

In the instrumental color measurements of pork emulsions added with NMI, all color traits of pork emulsions added with NMI showed significant differences with those of control (control vs NMI). In each group, the addition of SPI significantly increased the lightness, yellowness, chroma and hue angle values, and the addition of SC significantly increased the lightness, whiteness, yellowness, and hue angle values and decreased redness and chroma values. The addition of PBP significantly increased redness and whiteness values, and decreased yellowness, chroma and hue angle values. The quadratic regression of lightness $\left(\mathrm{L}^{*}\right)$ were significant in the SPI and SC treatments, and the PBP showed a not significant tendency $(p$-value $=0.065)$. In the redness $\left(\mathrm{a}^{*}\right)$, the linear regression was significant in the SC treatment $(p<0.01)$, and the quadratic regression was significant in the SC and PBP treatments $(p<0.01)$. In the yellowness, significant $p$-values of regressions were observed in the PBP (Quadratic) and SPI (Linear and Q) emulsions. The whiteness was significant at quadratic regression in all treatments $(p<0.05)$, and only significant at linear regression in SPI treatment. The chroma was significant in the quadratic regression of SPI and PBP treatments, and only SPI treatment was significant in the linear regression. In the hue angle, the three NMI (SPI, SC, and PBP) were significant in the quadratic regression, and the linear regression was significant only in the emulsion with SPI or SC except for PBP. Meanwhile, in the comparison of the PBP and SPI or SC, the pork emulsion with PBP significantly was higher in the lightness, yellowness, and hue angle than those of pork emulsion with SPI or SC, but the redness of pork emulsion with PBP were lower than those of pork emulsion with SPI or SC $(p<$ $0.01)$.

\section{Textural properties of pork emulsions}

The textural properties of pork emulsion with NMI were presented in the Table 3. The addition of NMI did not show significant effect on the textural property traits of pork emulsions. But, the hardness $(p$-value $=0.05)$ of pork emulsion tended to increase by the addition of NMI compared to the control (control vs NMI), whereas the other textural traits were not affected by the addition of NMI $(p>0.05)$. On the other hand, there was a significant difference in the gumminess between PBP and SC treatments $(p<0.05)$, the gumminess of pork emulsion with PBP was higher than that of pork emulsion with $\mathrm{SC}$, as well as the cohesiveness, chewiness, and adhesiveness values of pork emulsion added with PBP showed higher tendency than those of pork emulsion added with SC. Additionally there were no significant differences between the PBP and SPI pork emulsions. In the results of regressions, significances were only observed in the SPI treatment. Especially the hardness value of pork emulsion added with SPI was significant in the linear regression $(p<0.05)$, and the gumminess and chewiness values were significant in both linear and quadratic regressions $(p<0.05)$. Additionally, the addition of PBP had tendencies of significance on the regression results of hardness, gumminess, and chewiness.

\section{Discussion}

Many researchers reported that soy proteins can improve emulsifying ability and stability of processed meat products by gel formation between the soy proteins and components of meat 
Table 3. Effects of the non-meat ingredients on textural properties of pork emulsions

\begin{tabular}{|c|c|c|c|c|c|c|c|c|c|c|c|c|c|c|c|c|c|c|c|c|}
\hline \multirow{4}{*}{$\begin{array}{l}\text { Items } \\
\text { Treat- } \\
\text { ments }\end{array}$} & \multirow{4}{*}{$\begin{array}{c}\text { Control } \\
0 \% \\
1\end{array}$} & \multicolumn{15}{|c|}{ Non-meat ingredients (NMI) } & \multirow{2}{*}{\multicolumn{4}{|c|}{$\begin{array}{c}p \text {-value } \\
\text { Contrast }\end{array}$}} \\
\hline & & \multicolumn{5}{|c|}{ Soy protein isolated (SPI) } & \multicolumn{5}{|c|}{ Sodium caseinate (SC) } & \multicolumn{5}{|c|}{ Porcine blood plasma (PBP) } & & & & \\
\hline & & $0.5 \%$ & $1 \%$ & $2 \%$ & \multirow[b]{2}{*}{$\mathbf{L}^{2)}$} & \multirow{2}{*}{$Q^{3)}$} & $0.5 \%$ & $1 \%$ & $2 \%$ & \multirow[b]{2}{*}{ L } & \multirow[b]{2}{*}{$\mathbf{Q}$} & $0.5 \%$ & $1 \%$ & $2 \%$ & & \multirow[b]{2}{*}{$\mathbf{Q}$} & \multirow{2}{*}{ SEM } & \multicolumn{3}{|c|}{ PBP vs. } \\
\hline & & 2 & 3 & 4 & & & 5 & 6 & 7 & & & 8 & 9 & 10 & & & & $\begin{array}{l}\mathrm{NMI}^{4)} \\
\text { vs. }\end{array}$ & \multirow[t]{2}{*}{$\mathrm{SPI}^{5)}$} & $\mathrm{SC}^{6)}$ \\
\hline \multicolumn{20}{|c|}{ Textural properties } & \\
\hline $\begin{array}{l}\text { Hardness } \\
\quad(\mathrm{kg})\end{array}$ & $0.21 \pm 0.01$ & 0.22 & 0.23 & 0.23 & 0.042 & 0.119 & 0.21 & 0.23 & 0.19 & 0.817 & 0.509 & 0.20 & 0.25 & 0.22 & 0.092 & 0.060 & 0.01 & 0.052 & 0.887 & 0.139 \\
\hline $\begin{array}{l}\text { Cohesive- } \\
\text { ness (\%) }\end{array}$ & $0.60 \pm 0.02$ & 0.52 & 0.57 & 0.61 & 0.302 & 0.127 & 0.53 & 0.56 & 0.55 & 0.179 & 0.216 & 0.54 & 0.64 & 0.60 & 0.915 & 0.830 & 0.03 & 0.202 & 0.347 & 0.063 \\
\hline Springiness & $1.03 \pm 0.02$ & 1.03 & 1.00 & 1.07 & 0.192 & 0.235 & 1.00 & 1.00 & 1.02 & 0.371 & 0.447 & 1.00 & 1.05 & 1.02 & 0.444 & 0.471 & 0.03 & 0.670 & 0.843 & 0.464 \\
\hline Gumminess & $0.12 \pm 0.01$ & 0.12 & 0.13 & 0.14 & 0.011 & 0.027 & 0.11 & 0.13 & 0.11 & 0.503 & 0.623 & 0.11 & 0.16 & 0.13 & 0.069 & 0.075 & 0.01 & 0.357 & 0.861 & 0.027 \\
\hline Chewiness & $0.12 \pm 0.01$ & 0.12 & 0.13 & 0.16 & 0.021 & 0.041 & 0.11 & 0.13 & 0.11 & 0.342 & 0.597 & 0.11 & 0.17 & 0.13 & 0.073 & 0.102 & 0.01 & 0.535 & 1.000 & 0.056 \\
\hline $\begin{array}{l}\text { Adhesive- } \\
\text { ness (kg s) }\end{array}$ & $0.11 \pm 0.01$ & 0.10 & 0.11 & 0.11 & 0.823 & 0.969 & 0.10 & 0.12 & 0.10 & 0.361 & 0.650 & 0.10 & 0.13 & 0.12 & 0.116 & 0.257 & 0.01 & 0.487 & 0.125 & 0.067 \\
\hline
\end{tabular}

${ }^{1)}$ Data are Means \pm SEM of 9 and 5 replicates for the treatments 1 and $2-10$, respectively.

${ }^{2,3} \mathrm{~A} p$-values for the linear $(L)$ and quadratic $(Q)$ regressions, respectively.

${ }^{4-6)}$ Treatment 1 vs. $2-10,8-10$ vs. $2-4$ and $8-10$ vs. $5-7$, respectively.

$[15,28]$. Fukushima [29] described that soy proteins are composed of the major globulins such as $\beta$-conglycinin (7S) and glycinin (11S) proteins. However, Zhang et al. [30] found that the $7 \mathrm{~s}$ and 11s proteins were denatured at $70^{\circ} \mathrm{C}$ and $90^{\circ} \mathrm{C}$, respectively. Lin and Mei [1] also reported that salt soluble and water soluble proteins in SPI were denatured by heating temperature above $76.7^{\circ} \mathrm{C}$, and protective effect of soy proteins on meat proteins was not observed at high heating temperature (Approximately $68 \%$ denaturation rate of proteins at $82.2^{\circ} \mathrm{C}$ ). SC is composed of the major proteins such as $\alpha_{\mathrm{s} 1}$-casein and $\beta$-casein which can be used to prepare stable emulsion by the covering of fat globule, because both proteins exhibit a net negative charge at neutral $\mathrm{pH}$ and, are substantially amphiphilic with a high proportion of accessible non-polar residues, thus have a strong tendency to absorb at hydrophobic surfaces [31]. According to the study of Hurtado et al. [9], water holding capacity and cooking loss of pork sausage with added porcine plasma protein were not different with the sausages added SC and pentasodium tripolyphosphate. Also, Cofrades et al. [6] reported a similar result with the study of Hurtado et al. [9]. This is because that PBP protein contains necessary proteins such as albumin and globulin for emulsification. Feiner [15] described that blood plasma has a $\mathrm{pH}$ value of 7.4 to 7.8 , and addition of plasma for improvement of physicochemical properties slightly raises the $\mathrm{pH}$ in the meat product, resulting in increase of water-holding capacity. In this study, the concentrate of blood proteins was further increased unlike previous studies because of the freeze-dried blood plasma. In the study of Pietrasik et al. [32], cooking loss was not different among the pork gels added respective non-meat proteins (SC, PBP, and isolated soy protein at 2 $\mathrm{g} / 100 \mathrm{~g}$ ), and the $\mathrm{pH}$ values of pork gels also ranged from 5.87 to 6.26 , the highest $\mathrm{pH}$ values were observed in the pork gels containing sodium caseinateSC and porcine blood plasmaPBP. Previously, Chin et al. [33] reported that addition of 2.2\% SPI in the low-fat bologna sausage increased $\mathrm{pH}$ of sausage significantly. However, the $\mathrm{pH}$ result of this study was not similar to those of Chin et al. [33]. It is believed that this is due to the increase of $\mathrm{pH}$ by the addition of $14.9 \%$ fat in our emulsion formulation. On the other hand, Hsu \& Sun [34] indicated that the color values of pork meatball added with non-meat proteins. The lightness, redness and yellowness in the pork meatballs by addition of $4 \% \mathrm{SC}$ and $4 \% \mathrm{SPI}$ were not different compared with control significantly. However, in the result of Cofrades et al. [6], they reported that an increase in the proportion of plasma protein $(0 \%-5 \%)$ significantly increase lightness and yellowness values of pork sausage. 
According to the study of Herrero et al. [35], pork emulsion added with $2 \% \mathrm{NaCl}$ and $3 \%$ PBP powder showed higher hardness, springiness, and breaking force than pork emulsion with no addition, as well as frankfurters with 33\% PBP were significantly harder and chewer than those control sausages with $1.5 \% \mathrm{SC}$ and $0.15 \%$ tripolyphosphate, contrary to hardness and chewiness, control was more adhesive than frankfurters with $33 \%$ pork blood plasma [36]. In addition, Cofrades et al. [6] indicated that the hardness $(p<0.01)$, cohesiveness $(p<0.01)$ and chewiness $(p<0.001)$ in the pork sausage by addition of plasma protein $(0-5 \%)$ were significantly increased. Meanwhile, Suter et al. [37] concluded that the addition of $1 \%$ beef plasma protein increased binding strength in cooked ground beef, but the addition of $2 \%$ plasma protein had no significant difference compared with that. These trends were similar with regression results of texture properties in this study, although significances were rare in the linear and quadratic regressions. In addition, in the comparison of pork meatballs added with of 10 non-meat proteins including SC, whey protein, skimmed milk powder, soybean flour, soy proteins, wheat gluten, egg white powder, and gelatin, the hardness, adhesiveness, viscosity, chewiness, and gumminess values were higher in the meatballs added with SC or SPI than those of the others [34]. Until now, there were many studies that described the improvement effect of texture properties of each non-meat protein. But, it was not easy to find the study comparing the texture properties of SPI, SC, and PBP in pork emulsion. It is judged that additional experiments through different addition levels and processing methods are necessary.

\section{CONCLUSION}

To enhance quality characteristics such as binding ability, water holding capacity, and emulsifying ability of processed meat products, NMI are usually added to meat emulsion in the meat product industry. In this study, the emulsifying ability and quality characteristics of pork emulsions added with PBP or commercial NMI (SPI and SC) were compared. Our results revealed that pork emulsion added with PBP had similar emulsion stability and texture properties (based on the results of cooking loss, hardness, cohesiveness, gumminess, and chewiness) compared to pork emulsions added with SPI or SC. Our results revealed that pork emulsion added with PBP had similar emulsifying ability and texture properties compared to control and those added with SPI or SC. Therefore, PBP could be used as an emulsifying agent for pork emulsion products if its mass production system is in place industrially.

\section{REFERENCES}

1. Lin KW, Mei MY. Influences of gums, soy protein isolate, and heating temperatures on reduced-fat meat batters in a model system. J Food Sci. 2000;65:48-52. https://doi.org/10.1111/ j.1365-2621.2000.tb15954.x

2. Pietrasik Z, Duda Z. Effect of fat content and soy protein/carrageenan mix on the quality characteristics of comminuted, scalded sausages. Meat Sci. 2000;56:181-8. https://doi.org/10.1016/ S0309-1740(00)00038-3

3. Wismer PJ. Utilization of animal blood in meat products. Food Technol. 1979;33:76-80.

4. Parés D, Saguer E, Saurina J, Suñol JJ, Carretero C. Functional properties of heat induced gels from liquid and spray-dried porcine blood plasma as influenced by $\mathrm{pH}$. J Food Sci. 1998;63:958-61. https://doi.org/10.1111/j.1365-2621.1998.tb15832.x

5. Lu GH, Chen TC. Application of egg white and plasma powders as muscle food binding agents.J Food Eng. 1999;42:147-51. https://doi.org/10.1016/S0260-8774(99)00112-0 
6. Cofrades S, Guerra MA, Carballo J, Fernández-Martín F, Colmenero FJ. Plasma protein and soy fiber content effect on Bologna sausage properties as influenced by fat level. J Food Sci. 2000;65:281-7. https://doi.org/10.1111/j.1365-2621.2000.tb15994.x

7. Youssef MK, Barbut S. Effects of two types of soy protein isolates, native and preheated whey protein isolates on emulsified meat batters prepared at different protein levels. Meat Sci. 2011;87:54-60. https://doi.org/10.1016/j.meatsci.2010.09.002

8. Hyun CK, Shin HK. Utilization of bovine blood plasma obtained from a slaughterhouse for economic production of probiotics. J Ferment Bioeng. 1998;86:34-7. https://doi.org/10.1016/ S0922-338X(98)80030-5

9. Hurtado S, Saguer E, Toldrà M, Parés D, Carretero C. Porcine plasma as polyphosphate and caseinate replacer in frankfurters. Meat Sci. 2012;90:624-8. https://doi.org/10.1016/j.meatsci.2011.10.004

10. American Soybean Association. World soybean production. St. Louis, MO: American Soybean Association; 2016.

11. Yasumatsu K, Sawada K, Moritaka S, Misaki M, Toda J, Wada T, et al. Whipping and emulsifying properties of soybean products. Agri Biol Chem. 1972;36:719-27. https://doi.org/10.108 0/00021369.1972.10860321

12. Ramírez-Suárez JC, Xiong YL. Effect of transglutaminase-induced cross-linking on gelation of myofibrillar/soy protein mixtures. Meat Sci. 2003;65:899-907. https://doi.org/10.1016/S03091740(02)00297-8

13. Gao XQ, Hao XZ, Xiong GY, Ge QF, Zhang WG, Zhou GH, et al. Interaction between carrageenan/soy protein isolates and salt-soluble meat protein. Food Bioprod Process. 2016;100:47-53. https://doi.org/10.1016/j.fbp.2016.06.014

14. Alibhai Z, Mondor M, Moresoli C, Ippersiel D, Lamarche F. Production of soy protein concentrates/isolates: traditional and membrane technologies. Desalination. 2006;191:351-8. https://doi.org/10.1016/j.desal.2005.05.026

15. Feiner G. Meat products handbook: practical science and technology. Cambridge, UK: Woodhead; 2006. p. 672.

16. Dickinson E. Caseins in emulsions: interfacial properties and interactions. Int Dairy J. 1999;9:305-12. https://doi.org/10.1016/S0958-6946(99)00079-5

17. Chin KB, Go MY, Xiong YL. Konjac flour improved textural and water retention properties of transglutaminase-mediated, heat-induced porcine myofibrillar protein gel: effect of salt level and transglutaminase incubation. Meat Sci. 2009;81:565-72. https://doi.org/10.1016/j.meatsci.2008.10.012

18. Mathijs E. Exploring future patterns of meat consumption. Meat Sci. 2015;109:112-6. https:// doi.org/10.1016/j.meatsci.2015.05.007

19. Korea Testing Laboratory. The system development for production of amino acid liquefied fertilizer from slaughter blood. Sejong, Korea: Ministry of Agriculture, Food and Rural Affairs; 2015.

20. United States Department of Agriculture. Livestock slaughter 2016 summary. Washington, DC: United States Department of Agriculture: 2017.

21. Toldrá F, Aristoy MC, Mora L, Reig M. Innovations in value-addition of edible meat by-products. Meat Sci. 2012;92:290-6. https://doi.org/10.1016/j.meatsci.2012.04.004

22. Kim S, Jin S, Choi J. Effects of the addition of blood plasma proteins on physico-chemical properties of emulsion-type pork sausage during cold storage. J Sci Food Agric. 2017;97:45017. https://doi.org/10.1002/jsfa.8315

23. Hargin KD. Authenticity issues in meat and meat products. Meat Sci. 1996;43:277-89. https:// 
doi.org/10.1016/0309-1740(96)00072-1

24. Dàvila E, Parés D, Cuvelier G, Relkin P. Heat-induced gelation of porcine blood plasma proteins as affected by $\mathrm{pH}$. Meat Sci. 2007;76:216-25. https://doi.org/10.1016/j.meatsci.2006.11.002

25. Bloukas I, Honikel KO. The influence of additives on the oxidation of pork back fat and its effect on water and fat binding in finely comminuted batters. Meat Sci. 1992;32:31-43. https:// doi.org/10.1016/0309-1740(92)90015-V

26. Fernández-López J, Pérez-Alvarez JA, Aranda-Catalá V. Effect of mincing degree on colour properties in pork meat. Color Res Appl. 2000;25:376-80. https://doi.org/10.1002/15206378(200010)25:5<376::AID-COL9>3.0.CO;2-H

27. SAS. SAS Windows version 9.1.3. SAS Institute: Cary, NC; 2003.

28. Parks LL, Carpenter JA. Functionality of six nonmeat proteins in meat emulsion systems. J Food Sci. 1987;52:271-4. https://doi.org/10.1111/j.1365-2621.1987.tb06590.x

29. Fukushima D. Soy proteins. Food Res Int. 2004;45:1-23.

30. Zhang H, Takenaka M, Isobe S. DSC and electrophoretic studies on soymilk protein denaturation. J Therm Anal Calorim. 2004;75:719-26. https://doi.org/10.1023/b:jtan.0000027168.18317.78

31. Dickinson E. Surface and emulsifying properties of caseins. J Dairy Res. 1989;56:471-7. https://doi.org/10.1017/S0022029900028958

32. Pietrasik Z, Jarmoluk A, Shand PJ. Effect of non-meat proteins on hydration and textural properties of pork meat gels enhanced with microbial transglutaminase. LWT-Food Sci Tech. 2007;40:915-20. https://doi.org/10.1016/j.lwt.2006.03.003

33. Chin KB, Keeton JT, Longnecker MT, Lamkey JW. Utilization of soy protein isolate and konjac blends in a low-fat bologna (model system). Meat Sci. 1999;53:45-57. https://doi. org/10.1016/S0309-1740(99)00035-2

34. Hsu SY, Sun LY. Comparisons on 10 non-meat protein fat substitutes for low-fat Kung-wans. J Food Eng. 2006;74:47-53. https://doi.org/10.1016/j.jfoodeng.2005.02.022

35. Herrero AM, Cambero MI, Ordóñez JA, Hoz LDL, Carmona P. Plasma powder as coldset binding agent for meat system: rheological and Raman spectroscopy study. Food Chem. 2009;113:493-9. https://doi.org/10.1016/j.foodchem.2008.07.084

36. Hurtado S, Dagà I, Espigulé E, Parés D, Saguer E, Toldrà M, et al. Use of porcine blood plasma in "phosphate-free frankfurters". Procedia Food Sci. 2011;1:477-82. https://doi.org/10.1016/ j.profoo.2011.09.073

37. Suter DA, Sustek E, Dill CW, Marshall WH, Carpenter ZL. A method for measurement of the effect of blood protein concentrates on the binding forces in cooked ground beef patties. J Food Sci. 1976;41:1428-32. https://doi.org/10.1111/j.1365-2621.1976.tb01188.x 